\title{
A Derridarean critique of Logocentrism as opposed to Textcentrism in John 1v1
}

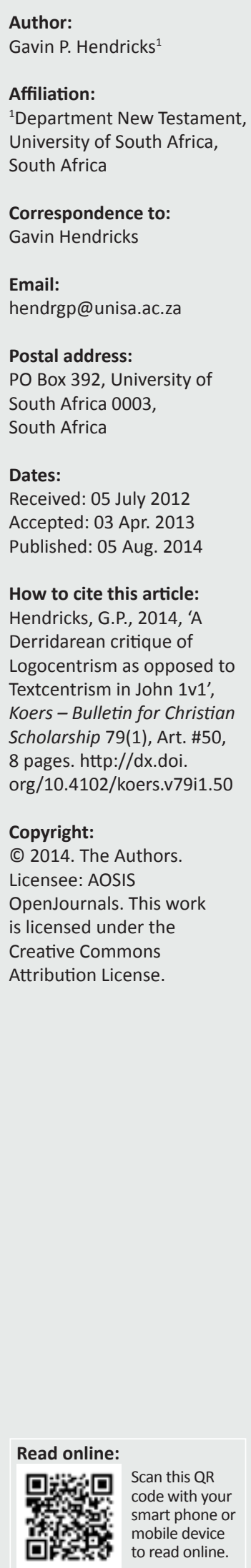

In Kelber's hermeneutics of John, the notion of the pre-existence Logos is central. The Logos, in his reading, is prior to the realm of history and outside the reality of the narrative text. I have argued that the Logos in John can be seen as a leading case of logocentrism as coined by Derrida. The term 'logocentrism' refers to the Graeco-Christian or Johannine Platonic tradition according to which written language belongs to the realm of the imperfect whereas true knowledge pertains to the pre-existent, personified Logos. Derrida provides an uncompromising critique of logocentrism. He read Western theology and philosophy not in terms of a fading logocentrism and a rise of textcentrism, but rather in terms of the illusion of logocentrism. Derrida's principle of distress is the referential paradigm of language. The linguistic sign is defined by the signifier and the signified. The signifier constitutes the visible marks committed to paper and the signified is the so-called meaning we attached to them. For Derrida, written language is generally seen as inferior whereas spoken language takes on transcendental significance and an ontological status to the referent of language. The Western tradition of philosophy and theology views writing as exterior whereas speech appears as innocent. Derrida's logocentrism approach challenges the privileging of speech over writing in the referential system, accusing Western theology and philosophy of falsely enslaving the sign by establishing a transcendental signifier over against writing. In this article, these ideas of Derrida are applied by reading the Logos in the Johannine narrative from the perspective of orality and textuality.

Derrida se kritiek op logosentrisme teenoor tekssentrisme: 'n Toepassing op Johannes $1 v 1$. In Kelber se hermeneutiek van Johannes is die pre-eksistensie van die Logos sentraal. Die Logos, volgens sy lesing, gaan vooraf aan die historiese gebied en staan buite die realiteit van die narratiewe teks. Ek het geargumenteer dat die Logos by Johannes beskou word as 'n eksemplariese geval van logosentrisme, soos Derrida dit omskryf het. Die term 'logosentrisme' verwys na die Grieks-Christelike of Johanneïese Platonistiese tradisie waarvolgens geskrewe taal tot die onvolmaakte hoort, terwyl ware kennis verband hou met die vooraf-bestaande, gepersonifieerde Logos. In sy werk bied Derrida 'n ongekompromitteerde kritiek op logosentrisme. Hy lees Westerse teologie en filosofie nie in terme van 'n wegvaag van logosentrisme en die opkoms van tekssentrisme nie, maar eerder in terme van die illusie van logosentrisme. Derrida se noodbeginsel is die verwysingsraamwerk vir taal. Die taalteken word omskryf deur die betekenaar en betekende. Die betekenaar konstitueer die sigbare merkies op die papier geplaas en die betekende is die sogenaamde betekenis wat ons aan hulle heg. Volgens Derrida word geskrewe taal in die algemeen as minderwaardig beskou terwyl gesproke taal transendentale betekenis verkry en 'n ontologiese status met betrekking tot die verwysing van taal. Die Westerse tradisie in filosofie en teologie sien skrywe as uiterlik terwyl praat as onskuldig verskyn. Derrida se logosentriese aanpak val die bevoorregting van praat bo skrywe in die verwysingsraamwerk aan en beskuldig Westerse teologie en filosofie dat dit die teken valslik verslaaf deur ' $n$ transendentale betekenaar teenoor skrywe te stel. In hierdie artikel is bogenoemde idees van Derrida toegepas deur die Logos in die Johanneïese narratief uit die oogpunt van oraliteit en tekstualiteit te lees.

\section{Introduction}

In John's Gospel, there is a shift from the charismatic speech (oral formula of the Logos) to the narrative text, where the status of Logos at the beginning of John 1v1 becomes the determiner of the logoi (words) in the Johannine narrative. Central to the oral and written hermeneutics of John's Gospel lies the idea of the pre-existent Logos. Being with Jesus metaphysically, the Logos is situated prior to the realm of history and outside the reality and construction of the written text. The written text cannot really be accorded full self-referentiality of the spoken word in the biblical text, because of its relation to the Father and the Spirit whose existence goes back to the beginning of creation. When viewed in relation to logoi (words in the narrative text), the Logos can be seen as normative, but when it is viewed in relation to the spoken Logos as a transcendental signifier, it 
appears in a less prominent position in the written text (Kelber 1987). The logoi or words in the biblical narrative of John have now been subordinated to the metaphysical authority of the Logos; this can be seen as only being in transition towards what is considered to be real, as it affirms the meaning and representation of reality for the 'other' in the Johannine narrative.

In the Greek, the Logos refers to word, reason, truth, logic and law. For Plato, Logos can be seen as a transcendent grounding principle of order and reason which gives meaning to discourse (Childers 1995:154-155). In the Gospel of John the Logos refers to the eternal word, which is equal to the metaphysical and ontological status of God. The Logos can be seen as a self-sufficient basis or self-identity by which all truth can be measured. It serves as a yardstick of all meaning. Linguistically, Logos refers to the 'meaning, presence, idea, intention' that exists behind the written text, whereas the spoken word serves as an adequate vehicle of expression (Childers 1995:154).

Logos is the meaning to which the sign refers. There is therefore a struggle between speech and writing and a domination of speech over writing as deconstruction launched an attack against the metaphysical construction of the sign. Logos is the name and the element of that which makes possible an absolutely pure and absolutely self-present self-knowledge. The Logos can be infinite and self-present and it can be produced as auto-affection only through the voice. An order of the signifier by which the subject takes from itself does not borrow outside of itself. This is at the consciousness of the voice hearing (understanding) oneself speak (Derrida 1976:98).

This article will focus on Jacques Derrida's critique of logocentric hermeneutics that tends to put an end to the priority of writing as self-referential. Derrida's method of deconstruction is connected to what he calls 'metaphysics of presence'. He denies this presence in the construction of the written text and the social construction of reality. He further argues that signs cannot refer to something other than themselves. There is no signifier that is independent of the signified: we are unable to escape the system of signifiers (Sarup 1988:38). Logos serves as a leading case for logocentric interpretive interest in the work of Derrida, who exposes the hierarchical oppression or the 'violent rape' of the spoken word in contrast to the written text. This leads me to examine Derrida's critique of logocentrism versus grammatology.

\section{Derrida's critique of Logocentrism versus Textcentrism}

Derrida's (1976) Of grammatology reads Western philosophy and theology not in terms of a fading logocentrism and a rise of textcentrism, but rather in terms of the illusion of logocentrism. Western philosophy has long been phonocentrically centred on the 'voice' and deeply suspicious of the script (written text). It has been, in the broader sense, logocentric, committed to the belief in some ultimate or axiomatic truths, for example: Logos, as a transcendental signifier that can be seen as presence, truth which acts as a foundation of all thoughts, language and experience in Western theology and philosophy (Sarup 1988:40). Derrida argues that such interpretive interest in meaning and representation can be seen as fictional and socially created by the West.

Logocentrism is being obsessed with the 'Word', or the big explanation of everything. It is the privileging of speech over the written word. Logocentrism, one of Derrida's concepts, has been defined as:

the illusion that the meaning of a word has its origin in the structure of reality and at the same time makes that truth part of that structure seem directly present to the mind. (Ellis 1989:36-37)

It is a desire to ascribe transcendental significance or metaphysics of presence to the signified.

Logocentrism is the privilege of the phōne, of the 'system of hearing oneself speaking' through the phonic substance, which presents itself as the non-exterior and therefore nonempirical or non-contingent signifier. It is centred on the idea of a full speech that is fully present, an originary speech itself shielded from interpretation (Evans 1991:148).

Husserl found evidence for self-presence in the voice (phōnē) - not the real voice, but the principle of the voice:

When I speak I hear myself and understand at the same time that I speak. In the act of speaking I seem to coincide with myself in a way quite different from what happens when I write. My spoken words seem immediately present to my consciousness and my voice becomes my intimate spontaneous medium. (Sarup 1988:39)

In our logocentric world, speech is privileged over writing because of its sense of proximity to the source of utterance. When I speak, the seal between my words and the meaning I intend remains intact, secured by my physical presence. For Derrida, the Logos as spoken word is the source of the entire Western tradition of metaphysics.

Within this Logos, the essential and original link to phōne has never been broken, and the essence of the phone would be immediately proximate to that which is thought, as Logos relates to meaning, produces it, speaks it, and composes it (Evans 1991:148).

Writing, by contrast, seems to drive a wedge between the speaker and his or her utterance. It is a secondhand mode of communication, a pallid mechanical transcript of speech, and so it is always removed from my consciousness. It is for this reason that the Western philosophical tradition from Plato to Lévi Strauss has consistently vilified writing as a mere lifeless, alienated form of expression and consistently celebrated the living voice (Sarup 1988:39). This led Derrida to wage a one-man 'deconstructionist' war against the entire Western philosophical and literary tradition of Rationalism or logical thought. He goes on to target the Western philosophical and theological central assumption of 'reason', which seems to be dominated by a 'metaphysics of presence' or the eternal Logos. For Derrida, 'reason' has been shaped by a dishonest pursuit of certainty, which can be seen as 'Logocentrism and the 
guarantee of the "Word made Flesh"' (Appignanesi 1992:76). The Western history of philosophy, theology and literature, from Plato, its founding father, and Aristotle, Kant and Hegel, right up to Wittgenstein and Heidegger, as well as Saussure, can be seen as a constant logocentric quest. Their works have contributed to the Western tradition of metaphysics (Moore 1994:28). In order to support a metaphysics of presence, the Western tradition has claimed that there is a supreme principle, 'Logos', that gives meaning to all discourse and organises all differences in a system of relationships (Ruf 1989:30).

Derrida criticised the Western tradition that made use of the logocentric model in order to absolutise meaning, seeing it as a dishonest construction of reality. His major concern is with the deviant modes of thought as he shows a persistent fascination with Judaism and the problem of its relation to Greek and Christian metaphysics. To be more precise, he has shown a fascination with writing, especially Judaism, and the problem of writing and its relation to 'Speech' in the Graeco-Christian metaphysics (Moore 1995:120). Derrida views the linguistic and theological concept of 'sign' as the root of logocentrism.

For Derrida, Western thought has always based itself on binary oppositions, for example, transcendent/immanent; spirit/flesh; primary/secondary; speech/writing; presence/ absence. In the Gospel of John these binary oppositions or two-storied structures seem to be evident, for example, knowledge/ignorance $(1: 10,26,31 ; 3: 10-11)$; spiritual/literal (2:19-21; 3:3-4), Spirit/flesh (1:18; 3:16); heavenly things/ earthly things (3:12), light/darkness (3:19-21; 1:7-9), Baptism in the Holy Spirit/water baptism (1:31; 3:5); heavenly ascent/descent $(1: 51 ; 3: 13 ; 3: 31)$. These binary oppositions can be seen as oppressive; moreover, the whole purpose of deconstructive hermeneutics is to dismantle or destroy such oppressive binary thinking, because there is no peaceful co-existence but rather violent hierarchy in the binary construction of the text (Moore 1995:27-28).

This suspicion is not just evident amongst post-structuralists across the academic spectrum, where this oppositionised binary thinking has been challenged. For example, this seems to be evident in our own context between androcentrism and feminism, white and black, the dominant ideology and marginalised oppressed communities, whereas there is a great need for liberation to take place against such dominant ideological structures. One of these logocentric binary oppositions to which Derrida directs special attention is that of 'Speech versus Writing'. Orality, as seen in the binary model of Saussure, has been treated as a transcendental signifier, whereas writing is treated as secondary.

In the following allegory, the history of speech began in a garden. They (Adam and Eve) heard the sound of God walking in the garden at the time of the evening breeze. The man and his wife hid themselves from the presence of God (Gn 3:8). The garden is speech, declared the Jewish poet, Edmond Jábes. Derrida extends Jábes's allegory:

God no longer speaks to us; he has interrupted himself: we must take words upon ourselves. We must intrust ourselves to traces because we have cease $[d]$ hearing the voice from within the immediate proximity of the garden. The difference between speech and writing is sin, ... lost immediacy, work outside the garden. (Moore 1995:29)

Outside the garden (allegory-speech), there is only sand and separation (writing). Writing is the moment of the desert or the moment of separation. Writing defaces presence. The relationship between speech and writing, Logos and the Book, is also an issue for Christianity, according to Ong (1982):

In Christian teaching orality and literacy polarities are particularly acute, probably more acute than in any religious tradition, even the Hebrew. For the Christian teaching the Second Person (Logos) of the One Godhead, who redeemed mankind from their sin, is known not only as the Son (Berâ) but also as the Word of God. In this teaching God the Father (Abbâ) utters or speaks his Word (Logos), his Son. He does not inscribe him. The very person of the Son (Berâ) is constituted as the Word (Logos) of the Father (Abbâ). Yet Christian teaching also presents at its core the written word of God, the Bible, which, back of its human authors, has God as $[A]$ uthor as no other writing does. (p. 179)

Although Derrida has written about the Bible (the Book) on occasion, he has never directly tackled the relationship of speech versus writing (orality and literacy binary) in the Jewish or Christian tradition. Within Aristotle's construction of meaning, speech and writing is the progress we have come to refer to as 'signification'. The spoken words are the symbols of mental experience (pathēmatatēs psychēs), whereas written words are the symbols of spoken words. This is because the voice, the producer of the first symbol, has a relationship immediately with the mind (Derrida 1976:11). He groups the three phenomena of thought, speech and writing into an essential duality.

Thought is symbolised by spoken words, which in return is symbolised by written words. Orality (speech) can be seen as innocence, whereas writing has fallen from that innocence. The pure originality of oral verbalisation is disrupted by writing. Writing seems to force itself on the natural condition of the Logos, even violating and raping it (Derrida 1976:29). Throughout Western history, speech has always been idealised at the expense of writing. This is clearly illustrated in the second Epistle of John as John writes to the 'elect lady': 'I would rather not use paper and ink, instead I hope to come to you face to face so that our joy may be completed (2 Jn 2)'.

When I speak, my words seem to be one with my thoughts. Meaning is present both to the hearer and to the speaker. What can be clearly observed is that speech creates presence but also authentic representation of meaning. Derrida (1973) in Speech and phenomena, says:

My words are alive, because they seem not to leave me: not to fall outside me, outside my breath, at a visible distance; not to cease to belong to me. (p. 76)

This is evident in the theological and philosophical names designated in the Western tradition, for example, God, truth and being, were endowed with a special sense of 'metaphysics 
of presence'. For Derrida, the Western thought of orality was a paradigm not just for every form of presence but for every form of truth. This can be seen as problematic as it becomes the centre and guarantor of presence (Moore 1994:28). This desire for centre or presence (onto-beingness) Derrida calls 'logocentrism'. Logocentrism refers to the Graeco-Christian or Platonic Johannine tradition according to which language - above all, written language - belongs to the realm of the contingent or metaphysical world (Kelber 1987:120).

The concept Logos in the Gospel of John carries the greatest meaning of 'presence'. The Logos is the origin of all things. The 'word' underwrites full presence, because everything is the effect of this one cause (Selden 1985:85). Even though the Bible is written, God's word is essentially spoken. The spoken word, filled with life, creates an intimate sense of presence. Logocentrism desires a perfect rational language that perfectly represents the real world. Such a language of reason would guarantee that the 'presence' of the world and the essence of everything in the world would be transparently (re)present(ed) in order to secure complete certainty (Appignanesi 1992:78). Words would be literally the truth of all things. John in the Fourth Gospel puts it that the 'Word became flesh' and so:

The binary opposition between speech and writing can thus be seen as a sin and oppressive, because it defaces every theology of presence. The written marks seems lifeless in the midst of living speech, cut off from the pneuma, the Spirit, breath (rūach). (Moore 1995:30)

Writing remains a threat to truth and a distortion of presence. The opposition of speech and writing can be seen as oppressive, where speech, being superior, belongs to the Logos (world of metaphysics) and a higher presence. Writing, the inferior term, marks a fall as it is seen as death.

In Socrates's account of the Egyptian story of writing there are two figures in the myth, Theuth, the inventor of writing, and Thamus, the king-god of all Egypt. Theuth presented his interventions to King Thamus, saying that his arts (technai) ought to be passed to the king's people. In Socrates's account, Theuth claims that letters will make the Egyptians wiser and improve their memories. He claims to have discovered an elixir (pharmakon: potion, remedy, medicine) for memory (mneme) and wisdom (sophia) (Irvine 1994:26). The king's response should be considered in full:

O man full of art, one man is given the power to create things of arts, and to judge the harm or usefulness to those who shall use them. And now you, who are the father of letters (pater grammaton), I have been led by your affection to ascribe to them a power opposite to that which they in fact possess. For this intervention will produce forgetfulness (lethe) in the minds of those who learn to use it; they will not exercise memory because they trust in writing, bringing things to remembrance not from within themselves. You have discovered an elixir not for memory (mneme) but for reminding (hypomneseos). You offer your students the appearance of wisdom, not true wisdom. For they will hear many things, while for the most part they are ignorant, and as men filled not with wisdom but with conceit of wisdom, they will be a burden to their fellows. (Irvine 1994:27)
In this version of the myth of the origins of writing, those who practised the art of letters depended on writing externally represented: an activity that suppresses remembrance, something within the soul, an art of words (logoi) applied like medicine to the soul for the benefit of health.

For Plato, writing displays a double sense of pharmakon medicine and poison. Writing anything put in grammata is not a medicine or pharmakon, but a poison to the soul. Writing is not clear and certain. Written words are of no use except as a reminder of that which they are written about (Irvine 1994:27). For Socrates, writing resembles a son-and-father relationship. For Socrates, words must have fathers. He claims that the relationship between spoken words and their fathers is more direct, more immediate, than the miserable relationship between the written text and their authors. Writing is like an orphan, and his father (of Logos) is nowhere to be found (Brogan 1989:1-24). Socrates views writing as dead and speech as living. This is clearly reflected in the following saying by him:

Once a thing is put into writing, the composition drifts all over the place, getting into the hands of not only those who understand it, but equally of those who have no business with it, it does not know how to address the right people and not address the wrong. And when it is ill-treated and fairly abused it always needs parents to come to its help. An orphan and a delinquent, no sooner born than set adrift, cut loose from the author who gave birth to it. Writing seems fated endlessly to circulate, if not from foster home to foster home, then from reader to reader, the best of whom can never be sure that he or she has fully what the author intended to say. (Moore 1994:30)

For Socrates, writing is like a painting, which generates a non-living being, which in return keeps silent when asked to answer. The written text is non-self-interpreting. Nothing is clear when left to writing. Besides this sterile sameness, writing is indifferent to its addressees. Writing wandering here and there is heedless of whom it reaches, and if disputes arise, or if it is unjustly despised, it still needs the help of the father. By themselves, written texts are unable to rescue themselves (Valdes 1991:333). For Socrates (Irvine 1994:27), writing can therefore be called an illegitimate child, a bastard brother, because it is silent to speak for itself when questioned. Socrates reflects this strongly in the following quotation:

What He does not say, but what is nevertheless true, is that the written word at its best fails to convey an illusion of the spontaneity of the spoken Logos, but with perfection of form as the premeditated speech seldom achieves, and conversely the spoken word, in the age of writing, aims at the considered structure of the written word, but without abandoning its own sense of immediacy and responsiveness to social use. (Greene 1951:152)

Though writing is supposed to help the memory, it actually leads to more forgetfulness, because it relies on the written characters rather than on memory. Moreover, the written word is not really intelligible or certain, nor is it better than knowledge; but it is a recollection of its subject-matter. Writing cannot answer questions, but can give unvarying answers. Better is the Logos written in the soul of the learner, that can defend itself, and that knows when to speak and 
when to be silent. What can be observed is that the presence of the author seems to be absent and even 'dead' as described by Roland Barthes, and that the meaning of the written text cannot be defended. It is not just the $[A]$ uthor who is 'dead' but also the property of writing. The main difference between the oral and the written word is the context. The speaker of an oral language relies more on context and non-verbal cues for communicating the verbal message (Greenfield 1972:169).

In primarily oral cultures, the word is closely related to power and action. It is dynamic, not static, and includes the sense that, once spoken, it is gone without the possibility of re-presentation. An oral representation is therefore an unrepeatable event in time, unlike written text, which is repeatedly read and referred to. Further, in primarily oral cultures, recitation of words to sound determines not only two modes of expression but also thought processes. You know what you recall (Ong 1982:33).

\section{Derrida's critique of the false consciousness construction of the metaphysics of presence}

Derrida's rejection of the logocentric model of the West is largely based on the fusion of Heidegger's and Nietzsche's critiques of Western metaphysics. Derrida refuses to accept that there is a transcendental signifier that gives meaning to all of history and truth. Meaning is not an illusionary constructed reality where the signifier and the signified are fused to create a 'sign' (semeion). For Derrida, the meaning of the sign comes from another sign and not from outside the realm of objectivity. He opposes the idea that there is something like literal or true meaning or absolute meaning in the understanding of the social construction of reality (Leitch 1988:277-282).

The rejection of any literal or true meaning shifts the interpretation from the transcendental signifier to the reader, who needs to interpret the text. Meaning is reduced to the self and there can be many legitimate understandings of the written text or different perspectives. Meaning is never full 'presence' in a sign system but always a substitute (Norris 1982:32).

Derrida's argument is that no meaning can be finalised in a 'speech act', because it is in the nature of a text that writing can be cited:

Every sign, linguistic or non linguistic, spoken or written, as small or large unity, can be cited, put between quotation marks; thereby it can break with every given context, and engender infinitely new contexts in an absolutely non saturable fashion. (Easthrope 1988:167)

For Derrida, there is no 'single' meaning that can saturate the text, because the text can always be interpreted beyond its original context. The written sign is a mark that can be repeated in the absence not only of the subject who is uttered in a specific context but also of a specific addressee. The written sign is not bound to a specific context, but it breaks its real context and can be read in a different context regardless of what the author's intention is or its social, historical sitz im leben [position in life] is. The written sign is subject to spacing, because it is separated from other signs in the particular chain of differences; furthermore, it is separated from 'present reference' (that is, it can refer only to something not present) (Selden 1985:88). Writing involves a certain irresponsibility, because if signs are repeatable out of context, then 'What authority does it possess in the light of meaning and representation?'

Derrida agreed that some interpretations are more powerful than others, because meaning is determined by a system of forces that is not personal. It does not depend on the subjective identity, but on the field of different forces, the conflict of forces that produce interpretations (Easthrope 1988:168). Meaning is a product of the interplay of differences. There are no final meanings to the signification process. This means that the signifier is not subordinated to the signified. For Derrida, the absence of the transcendental signified extends the realm and the play of signification to infinity (Degenaar 1992:201). For Culler (1982:123), meaning is context bound, but the context is boundless. The context itself is a text that must be interpreted. Meaning can be interpreted as a product of a play of differences in a text within a context. Both context and text must always be defined, delimited, read, and interpreted.

The written text has been described in various ways, depending on the paradigm used by the speaker. The written text is seen as a document producing information in the mind of the writer and his or her view of life. The written text can be seen as a monument with its own autonomy, [a] timeless, self-possessed structure of meaning. (Degenaar 1992:200)

A written text is a happening in which signs and the traces of signs make themselves available to the reader for the adventure of understanding. The text is an episode in the all-encompassing textuality. For Derrida, there is nothing outside the written text or there is nothing outside of context (Degenaar 1992:200).

Derrida refuses to accept that there is something like 'oral text', because this leads to the Structuralists and Form critics who want to imprison the oral formulae of the Logos and reduce it to writing (Fuchs 1994:401). He further argues that meaning must be free from the prison house of the Western tradition that has enslaved the written text with a dishonest metaphysics of presence. This violent hierarchy between speech and writing as constructed by the structuralists is an economy of power. This economy of power exists amongst the literate, who violently want to secure meaning over speech by drawing on the assumption that there are structured forms in the written text (Ruf 1989:31).

This remains a question of debate because with structured forms come boundaries and social maintenance of the written text. Immediately, an axiomatic expression can be seen as a false identity of the written text. Derrida insists that the oppressive hierarchy between speech and writing must 
be destabilised and even collapsed in order to free meaning from these oppressive hierarchical structures. The premise for meaning is built on a false identity that is constructed on the metaphysics of presence. The whole purpose of the ideology of representation is to privilege speech over writing, and to establish a regime of power and a disciplinary exclusion (Fuchs 1994:401).

The question that rests with the reader is, 'How do you overthrow this oppressive hierarchy between logocentrism as opposed to textcentrism?' Derrida proposes that the reader needs to point out its arbitrary status, and then has to cancel out 'truth' or 'Logos' and its will to power, because the dominant discourse or the Western tradition has established oppressive viewpoints. When interpreting oral signs, the reader has to recognise certain fixed and identical forms in the written text and whatever accent or distortion may be involved in the utterance of the word. It calls on the reader to exclude the accidental 'phonic' sound and then to recover the pure form. This form is the repeatable signifier thought characteristic of writing (Selden 1985:88). What can be observed is that speech is a product of writing.

Derrida's re-situation of the 'self' at the margins relates directly to the notion of 'intertextuality', where the reader is a 'text', one of many 'texts' involved in the act of reading. His concept of 'text' is not synonymous with 'book or scriptism'.

A text is henceforth no longer a finished corpus of writing, some content enclosed in a book or its margins, but a differential network, a fabric of traces referring endlessly to something other than itself, to other differential traces (Long 1992:50-64).

For many, the concept of the 'text' in the work of Derrida has created a great amount of confusion. Writing for Derrida is 'free play' or the element of undesirability within every system. Derrida's 'endless play' grows out of an encounter with another text, for example, text from Plato, Rousseau and the work of Saussure (Bryant 1989:73).

In speech, the signifier (voice) and the signified (meaning) are given together. Form and meaning are immediately perceived. Voice, intonation, gesture, and the other communicative devices used by both speaker and receiver help to clarify the meaning of the message. Writing is different because the signifier is in the form of words that have many possible forms of meaning once they are separated from the person who wrote them. Therefore, the signified (the meaning) is not given: it must be interpreted by the reader. This is what Derrida calls 'free play' of words that can never be 'pinned down' to a meaning (Bryant 1989:73, 75). Words are simply floating with no meaning attached to them; there is no common meaning to be found.

Derrida takes this notion of 'free play' a step further as he expands it beyond the binary debate of speech and writing and begins to question the whole concept of structure or centre of the written text. There is: [no] absolute meaning outside and above the world of discourse that gives significance to the whole interpretive interest, there is no centre to define and guide interpretation. Rather, there is free play between the signifier and the signified, i.e. the message takes on a different meaning depending on who is receiving or reading it. (Bryant 1989:73-75)

To Derrida, the concept of a centre (Logos) to a structure is non-existent. Writing remains an endless displacement of meaning that places language beyond the reach of any stable or self-authenticating knowledge. For Derrida, oral language belongs to a generalised writing that is ever disguised by the illusion of the metaphysics of presence (Norris 1982:29-32). The craving of writing for a self-presence and a self-identity is withheld by phonocentrism, which views speech as privileged over writing. This leads to a rejection of the logocentric model of the West. Derrida rejects all forms of logocentrism, as he claims it is a form of onto-theology that denies the social, historical, finite and contingent character of human thought. Logocentrism fails to see that meaning is tied to human beings, which is a changing system of relations. Logocentrism is an onto-theological attempt to evade the recognition of human finitude that is able to give meaning to the written text as it undermines the philosophy of idealism and Western humanism (Ruf 1989:320).

In the philosophy of Descartes, whose premise was built on methodological doubt of the written text, he came to realise that one cannot doubt oneself in relation to the meaning of text. This is clearly stated in the following words, 'Cogito, ergo sum' [I think, therefore I am]. The ' $\mathrm{I}$ ' becomes the determiner of the written text. What is evident in the hermeneutics of Derrida is a paradigmatic shift from the Western tradition whose underlying basis for meaning is deeply rooted in the metaphysics of presence to the ' $\mathrm{I}$ ' or self-identity that determines the meaning of discourse.

Martin Buber, the Jewish philosopher, put this into closer perspective, in view of the 'I and Thou' theory, which reveals a relationship between Logos and human beings (the metaphysics of presence and homo sapiens) and gives meaning to the ' $\mathrm{I}$ ' and its reality and the meaning of the written text and context. He became less interested in perceiving the mind or life experience of the author behind the written text. He is more concerned with the integrity of the text, in developing a dialogical relationship with the text, and a dialogue between the speaker and the context (Kepnes 1988:193-213).

According to Coleridge (see Perkins 1994), the primary word I-Thou can only be spoken with the whole being (personhood) and all language and meaning is fundamentally rooted in the divine Logos. Every word that proceeds from a person's mouth in whom 'will and reason' are united is in itself analogous as a symbol of the divine Logos (ibid:271).

For Froman (1991), Gadamer is the one that 'presents the hermeneutical problem in all its purity' because writing is a kind of alienated speech. Self-alienation takes place when meaning is written down, that is to say 'inscripted'. The written signs per se are incapable of yielding any meaning, 
unless they are transformed back into speech and meaning. The weakness of writing is the lack of support for the written inscription from the circumstances of its inscription (Froman 1991:139). The sign language refers back to the actual language of speech. For Gadamer, writing needs to be extended to aesthetics, the whole sphere of art and its complex questions. He later notes that the meaning of the text extends also to oral utterances (interface between oral and written orality) and that Schleiermacher first discerned this truth at the turn of the 19th century (Gadamer 1985:353).

Derrida rejects the perspective of Western meaning and representation as he views the whole constructed reality of meaning as an illusion. The 'I and it' gives meaning to the written text. The 'I' refers to the self-identity, and the 'it' refers to the written text, for the ' $I$ ' determines the meaning of the written text. Linguistically, the ' $I$ ' referred to 'floaters' (it means whoever says it). The ' $\mathrm{I}$ ' is not attached to a designatable object or a person but it refers to the individual's own personal world or awareness (Ong 1995:22).

The undecidability of writing is not a matter of the bare play of signifiers, but rather an undecidability of writing as decentring. Derrida's attack is against the constant danger of attributing 'presence' and meaning to the Logos. His attack is not against the human need to seek truth, nor does he deny that truth can be found; his major argument against logocentrism is that truth cannot be found in the 'metaphysics of presence' or logocentrism because that is no truth. It falls outside the realm of scientific objectivity. What we claim to be truth can be seen as a questionable phenomenon.

The whole objective of deconstructionist hermeneutics is to adhere to these marginalised voices and to empower the reader to decide on the meaning of a written text. For Derrida, the written text can no longer be compared to an extra-mental or external social or primordial reality such as Logos. The written text remains a social construct of the West in the production of knowledge, because beyond the written text are only traces of more written text. The sign points to other signs and it no longer refers to an independent reality outside of the world (kosmos), because there is nothing outside of written text - in other words, there is nothing outside of context.

Writing distances the word from the plenum of existence. In the spoken condition, words are always part of context that is predominantly non-verbal. The immediate context of spoken words is never simply other words. Context always controls the meaning of a word (Ong 1988:39). In primary oral communities the source (speaker) and the recipient (hearer) are present to one another in order to affirm meaning and representation. For words are sounds, and sounds are events. Words modify the holistic situation and in one way or another they explain and interpret it:

It is in orality that the verbal expression has its origin. The oral Word is essentially a call, a cry. It is not a thing or a reification, but an event, an action. The oral word is a call from someone to someone, an interpersonal transaction. No interactive persons, no words. The oral word in meaning and representation is a unique kind of event, to whom the word is addressed, called out, cried out (...) the oral word is a call, a cry, addressed to another person. The oral word is essentially explanation or interpretation, a clarification by one person of something to his or her interlocutor. (Ong 1988:259-269)

There is no centre from which one can finalise meaning, as the trained reader becomes creatively involved in the play of significations. Meaning cannot be finalised by linking the written text to the writer's intention (structuralism, historical critical method) as a source of meaning. Interpretation is not to recover some meaning that lies behind the written text, but to participate in a play of possible meanings.

\section{Conclusion}

It may be argued that Derrida, who opposes the Western tradition of 'metaphysics of presence' that is rooted in the eternal concept of Logos or metaphysics of presence, agrees that it is impossible to overthrow it, because it existed at the beginning of creation ( Jn $1 \mathrm{v} 1$ ) or outside the realm of scientific objectivity. Hermeneutically, deconstruction is viewed by some textual critics in the Husserlian tradition as a new paradigm that can resolve and even destroy the basic structures of logocentric interpretative interest in Western thought. As much as Derrida wants to change the oppressive binary oppositions between speech and writing, deconstruction continues to affirm the ideology of the written text in relation to the power of speech or metaphysics of presence. Binary oppositions represent a way of seeing ideologies and power relationships in the text through ideas and conceptual frameworks.

In the context of the Johannine Logos (transcendental signifier) readers and hearers let themselves be guided by the narrative dynamic to move from plural experience of the logoi (words) to that of the singular Logos which now takes command over the narrative text. The written text was therefore not considered with ultimate seriousness. The Logos does not represent an extra-linguistic mode of authority but an extratextual one (Kelber 1987:128). Logos can therefore be seen as an appropriate metaphor for transcendence or the metaphysics of presence. Like oral speech, the Logos is ephemeral. It has no visual or physical means of preservation and it manifests itself in a moment of verbal action. Its prime potency is sound, which is a strong characteristic of divinity and Spirit.

\section{Acknowledgements Competing interests}

The author declares that he has no financial or personal relationship(s) that may have inappropriately influenced him in writing this article.

\section{References}

Appignanesi, R., 1992, Postmodernism, Icon Publishers, New York.

Brogan, W., 1989, 'Plato's Pharmakon: Between two repetitions', in H.J. Silverman (ed.), Derrida and deconstruction, pp. 1-24, H.J. Routledge, London. 
Bryant, M.D., 1989, "From "De" to "Re" or does the "Future of onto-theology" require the recovery of the experience/sense of transcendence?', in H. Ruf (ed.), Religion, onto-theology and deconstruction, pp. 73-75, Paragon House, New York.
ont

Childers, J., 1995, The Columbia dictionary of modern literary and cultural criticism, Columbia University Press, New York.

Culler, J., 1982, On deconstruction: Theory and criticism after structuralism, Routledge, London.

Degenaar, J., 1992, 'Deconstruction - The celebration of language', in B. Lategan (ed.), The reader and beyond: Theory and practice in South Africa Reception Studies, pp. 200-220, Human Sciences Research Council Publishers, Pretoria.

Derrida, J., 1973, Speech and phenomena and other essays, transl. D.B. Allison, Northwestern University Press, Evanston.

Derrida, J., 1976, Of grammatology, transl. G.C. Spivak, Johns Hopkins University Press, Baltimore.

Easthrope, A., 1988, British post-structuralism, Routledge, New York.

Ellis, J., 1989, Against deconstruction, Princeton University Press, New Jersey.

Evans, C.J., 1991, Strategies of deconstruction, University of Minnesota Press, Minneapolis.

Froman, W., 1991, 'L'ecriture and philosophical hermeneutics', in H.J. Silverman (ed.), Gadamer and hermeneutics, p. 139, Routledge, London.

Fuchs, S., 1994, 'What is deconstruction?', American Sociological Review 59(4), 401.

Gadamer, H.G., 1985, Truth and method, Crossroads, New York.

Greene, W., 1951, 'The spoken and written word', Harvard Studies of Classical Philology 60, 152. http://dx.doi.org/10.2307/310884

Greenfield, P., 1972, 'Oral or written language: The consequences for cognitive development in Africa, the United States and England', Language and Speech 15 169. PMid: 4653683

Irvine, M., 1994, The making of a textual society, Cambridge University Press, Cambridge.
Kelber, W.H., 1987, 'The authority of the word in St John's Gospel: Charismatic speech, narrative text, logocentric metaphysics', Journal of Oral Tradition 2(1), 108-131.

Kepnes, S.D., 1988, 'Buber as Hermeneut', Harvard Theological Review 81(2), 193-213. http://dx.doi.org/10.1017/S001781600001004X

Leitch, B.V., 1988, American literary criticism from the thirties to the eighties, Columbia University Press, New York.

Long, T.M.S., 1992, 'Deconstruction and biblical studies in South Africa', Scriptura 42, 50-64.

Moore, S., 1994, Post-structuralism and the New Testament, Fortress Press, Minneapolis.

Moore, S., 1995, Postmodern Bible, Yale University Press, New Haven, Yale.

Norris, C., 1982, Deconstruction theory and practice, Routledge, London. http://dx.doi. org/10.4324/9780203426760

Ong, W.J., 1982, Orality and literacy: The technologizing of the word, Methuen, New York. http://dx.doi.org/10.4324/9780203328064

Ong, W., 1988, 'Before textuality: Orality and interpretation', Oral Tradition 3(3), 259-269.

Ong, W., 1995, 'Hermeneutics forever: Voice, text, digitization, and the I', Oral Tradition 10(1), 22.

Perkins, M.A., 1994, Coleridge's philosophy: Logos as a unifying principle, Clarendon Press, Oxford. http://dx.doi.org/10.1093/acprof:0so/9780198240754.001.0001

Ruf, H., 1989, Religion, onto-theology and deconstruction, Paragon Press, New York.

Sarup, M., 1988, Post-structuralism and post-modernism, Harvester Wheatsheaf, London.

Selden, R., 1985, A reader's guide to contemporary literary theory, Harvester Press, London.

Valdes, M., 1991, A Ricoeur reader, Harvester Wheat Sheaf, Canada. PMCid:PMC1972379 